\title{
EFFECT OF LIGHT INTENSITY ON THE PERFORMANCE OF SILICON SOLAR CELL
}

\author{
MARTIAL ZOUNGRANA, ISSA ZERBO, MAHAMADI SAVADOGO, SANNA TIEDREBEOGO, \\ BOUBACAR SORO AND DIEUDONNÉ JOSEPH BATHIEBO
}

(Received 31 January 2017; Revision Accepted 7 April 2017)

\begin{abstract}
This work, presents the intense light effect on electrical parameters of silicon solar such as short circuit current, open circuit voltage, series and shunt resistances, maximum power, conversion efficiency, fill factor. After the resolution of the continuity equation which leads to the solar cell photocurrent and photovoltage expressions, we use the J/V characteristic to determine the solar cell series and shunt resistances. The maximum electric power of the solar cell is determined using the curves of electric power versus junction dynamic velocity, and then, the fill factor and conversion efficiency are calculated. Light concentration and junction dynamic velocity effects on solar cell short circuit current, open circuit voltage, series and shunt resistances, electric power, fill factor and conversion efficiency are also studied. The study proved that with increase of illumination light intensity, the solar cell shunt resistances decreases whereas series resistance, short circuit current, open circuit voltage, electric power, fill factor and conversion efficiency increases.
\end{abstract}

KEYWORDS: Light concentration, series resistance, shunt resistance, electric power, fill factor, Conversion efficiency

\section{INTRODUCTION}

Illumination level is one of the main factors which characterizes the electric power and conversion efficiency of a silicon solar cell. Conversion efficiency can also be influenced by the solar cell's series and shunt resistances. Experimental and modelling methods of light effects on solar cell's parameters were proposed in many studies: Intense light concentration silicon solar cell [Pelanchon et al., 1992], high concentration solar cell [Zoungrana, et al., 2012], bifacial silicon solar cells [Ohtsuka, et al., 2001], rear-floating-emitter solar cell and triode [Gupta, et al., 2002], n-C/p-Si heterojunction solar cell [Vardanyan, et al., 1998].

It was proved in previous studies [Zoungrana, et al., 2011] that light intensity has an influence on solar cell photocurrent and photovoltage. Comparative studies conducted on light effect on solar cells show that light causes less damage on solar cells manufactured with (MCZ) and $\mathrm{CZ}(\mathrm{Ga})$ materials than those manufactured with FZ materials [Ohtsuka, et al., 2001].

The light concentration effect on the distribution of carriers in the base of a silicon solar cell was simulated by Pelanchon et al. [Pelanchon et al., 1992] for two base doping levels in order to compare it with the experimental ones. It appears in this study that the profiles of carriers distribution obtained through simulation and experience are identical for the two base doping level. Khan et al. [Khan et al., 2010] proposed also a study based on a diode model of illumination intensity effect on the parameters of a silicon solar cell. This study put in evidence that the shunt resistance increases lightly with illumination intensity and then becomes constant at higher values of illumination. However, series resistance, ideality factor and short circuit current decrease continuously with illumination intensity, but the rate of decrease of each of these parameters becomes smaller at higher illumination intensity. In order to investigate the illumination effect on solar cell, Deme et al. [Deme et al., 2010] proposed a three dimensional study of illumination incidence angle effect on a silicon solar cell capacitance and its efficiency. This study pointed out that the solar cell capacitance increases with illumination incidence angle from 0 to $\pi / 2 \mathrm{rad}$ and decrease from $\pi / 2 \mathrm{rad}$ to $\pi \mathrm{rad}$.

Since solar cell electrical parameters such as short circuit current, open circuit voltage, electric power, conversion efficiency and fill factor are directly link to charge carriers distribution in the base, the illumination level, which is a source of carrier photogeneration,

Martial Zoungrana, Laboratory of Thermal and Renewable Energies, Department of Physics, Unit of Training and Research in Pure and Applied Sciences, University of Ouagadougou Professeur Joseph KI-ZERBO, Burkina Faso

Issa Zerbo, Laboratory of Thermal and Renewable Energies, Department of Physics, Unit of Training and Research in Pure and Applied Sciences, University of Ouagadougou Professeur Joseph KI-ZERBO, Burkina Faso

Mahamadi Savadogo, Laboratory of Thermal and Renewable Energies, Department of Physics, Unit of Training and Research in Pure and Applied Sciences, University of Ouagadougou Professeur Joseph KI-ZERBO, Burkina Faso

Sanna Tiedrebeogo, Laboratory of Thermal and Renewable Energies, Department of Physics, Unit of Training and Research in Pure and Applied Sciences, University of Ouagadougou Professeur Joseph KI-ZERBO, Burkina Faso

Boubacar Soro, Laboratory of Thermal and Renewable Energies, Department of Physics, Unit of Training and Research in Pure and Applied Sciences, University of Ouagadougou Professeur Joseph KI-ZERBO, Burkina Faso

Dieudonné Joseph Bathiebo, Laboratory of Thermal and Renewable Energies, Department of Physics, Unit of Training and Research in Pure and Applied Sciences, University of Ouagadougou Professeur Joseph KI-ZERBO, Burkina Faso 
influences these electrical parameters. In previous work [Zoungrana et al 2011,], the effect of intense light illumination have been studied on the carrier distribution in the base of a silicon solar cell. It appeared in this study that carrier photogeneration, junction recombination velocity and back surface recombination velocity increases with light intensity.

In this work we studied the effect of intense light illumination level on short circuit current, open circuit voltage, series and shunt resistances, electric power, fill factor and conversion efficiency.

\section{MODEL AND ASSUMPTIONS}

1.1. Analytical formulation

The model of silicon solar cell operating under an intense light concentration is given by figure 1 below. The light penetrates the junction at the plane $x=0$. Because of the light intensity, carrier concentration in the base is not uniform. So, we take into account the electric field $E(z)$ due to the difference of carrier concentration on $x$ axis : $\vec{E}(x)=-E(x) \vec{i} \quad$ [Pelanchon et al., 1992].

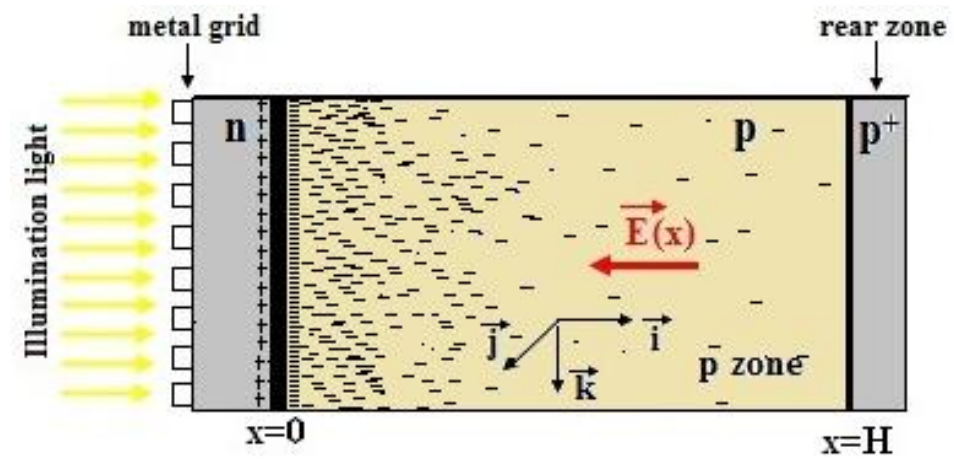

Figure 1: Silicon solar cell under intense light illumination

Taking into account the intense light concentration electric field $\vec{E}(x)$, the expression of photocurrent density in solar cell base $\vec{j}_{n}$ is given by the equation of transportation phenomenon in Eq. 1 [Zoungrana, et al., 2012].

$$
\overrightarrow{J_{n}}=e D_{n} \vec{\nabla} \delta+e \mu_{n} \delta \vec{E}
$$

The expression of the electric field of carrier concentration gradient is given by Eq. 2 [Pelanchon et al., 1992].

$$
\vec{E}(x)=\frac{D_{p}-D_{n}}{\mu_{p}+\mu_{n}} \cdot \frac{1}{\delta(x)} \frac{\partial \delta(x)}{\partial x}
$$

where $D_{n}$ and $D_{p}$ are respectively electrons and holes diffusion coefficients, $\mu_{n}$ and $\mu_{p}$ are electrons and holes mobility, $e$ is the elementary charge and $\delta(x)$ is the excess minority carrier density in the base of the illuminated solar cell.

\subsection{Determination and resolution of continuity equation}

The resolution of Eq. (1) taking into account the oxnreccion of olestrir fiold dise th the rarriar concentration gradient given by Eq. (2) leads to the electron photocurrent density expression along the $x$ axis:

$$
J_{n x}=e\left[\frac{D_{n} \mu_{p}-D_{p} \mu_{n}+2 D_{n} \mu_{n}}{\left(\mu_{n}+\mu_{p}\right)}\right] \frac{\partial \delta(x)}{\partial x} \ldots \ldots
$$

The expression of the photocurrent density can be simplified as:

$J_{n x}=e D_{e} \frac{\partial \delta(x)}{\partial x}$ with $D_{e}=\frac{D_{n} \mu_{p}-D_{p} \mu_{n}+2 D_{n} \mu_{n}}{\left(\mu_{n}+\mu_{p}\right)} \ldots$

$D_{e}$ is the new expression of the diffusion coefficient of the solar cell under intense light concentration.

In steady state, the general expression of excess minority carriers distribution in the base of the solar cell along the $x$ axis is given by Eq. (5) [Pelanchon et al., 1992; Deme et al., 2010; Zouma et al., 2009]:

$$
\frac{\partial^{2} \delta(x)}{\partial x^{2}}-\frac{\delta(x)}{L_{e}{ }^{2}}+\frac{G(x)}{D_{e}}=0
$$

$L_{e}$ is the new expression of diffusion length of the solar under intense light concentration, $G(x)$ is the generation rate of excess minority carrier [Deme et al., 2010; Sané et al., 2015]: $\quad G(x)=C \cdot \sum_{i=1}^{3} a_{i} \cdot e^{-b_{i} x}$ 
and $a_{i}$ and $b_{i}$ are deduced from modelling of the generation rate considered for over all the solar radiation spectrum [Zoungrana et al., 2011, Deme et al., 2010; Sané et al., 2015] C is solar light intensity expressed in suns. The solution of the distribution equation Eq. (6) is:

$$
\delta(x)=A \operatorname{ch}(\alpha x)+B \operatorname{sh}(\alpha x)+\sum_{i=1}^{3} K_{i} e^{-b_{i} x}
$$

$$
\text { With } \alpha=\frac{1}{L_{e}} K_{i}=\frac{C \cdot a_{i}}{D_{e}\left(L_{e}{ }^{-2}-b_{i}{ }^{2}\right)}
$$

The coefficients $A$ and $B$ are obtained by solving the boundary conditions equations at the two edges of the base region $(x=0$ and $x=H$ ) [Pelanchon et al., 1992; Zoungrana et al., 2011; Zouma et al., 2009].

\subsection{Expression of photocurrent density and photovoltage}

Knowing the carrier distribution in the base of the solar cell, we can deduct the expressions of photocurrent and photovoltage as given in following equations (7) and (8):

$$
\begin{aligned}
& J_{p h}\left(S_{f}\right)=\left.q D_{e} \frac{\partial \delta(x)}{\partial x}\right|_{x=0} \ldots \ldots \ldots \ldots \ldots \ldots . . . . . . \\
& V_{p h}\left(S_{f}\right)=V_{T} \cdot \ln \left[1+\frac{\delta\left(x=0, S_{f}\right)}{n_{0}}\right]
\end{aligned}
$$

where $q$ is electric charge, $V_{T}$ is the thermal voltage given by: $\mathrm{V}_{\mathrm{T}}=\mathrm{k}_{\mathrm{B}} \cdot \mathrm{T} / \mathrm{q}, n_{0}$ expresses the carrier concentration at thermodynamic equilibrium: $n_{0}=n_{i}^{2}$ / $N_{B} . n_{i}$ represents the intrinsic carrier concentration $\left(n_{i}=\right.$ $10^{10} \mathrm{~cm}^{-3}$ for silicon), $N_{B}$ is the base doping density $\left(N_{B}\right.$ $=10^{16} \mathrm{~cm}^{-3}$ ) and $\mathrm{k}_{\mathrm{B}}$ is the Boltzmann's constant.

\subsection{Expression of series and shunt resistances}

The series and shunt resistances are respectively deduced from the behavior of the solar cell near the open circuit and the short circuit. In fact, on the $J-V$ characteristic, near the short circuit, the solar cell behaves like an ideal current generator associated with a shunt resistance [Sissoko et al., 1998; Garrido et al; 1999].

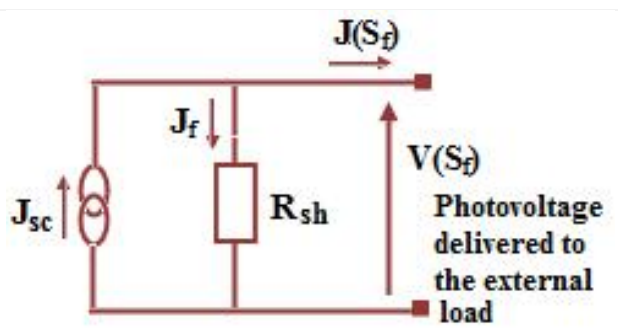

Figure 2: Equivalent electrical model of the solar cell in short circuit
A part of the short circuit current is derived in the shunt resistance. The expression of the photovoltage across the external load is:

$$
V_{p h}\left(S_{f}\right)=R_{s h} \cdot\left(J_{s c}-J\left(S_{f}\right)\right)
$$

And then, shun resistance can be deduced as :

$$
R_{s h}=\frac{V\left(S_{f}\right)}{\left(J_{s c}-J\left(S_{f}\right)\right)}
$$

$J_{S C}$ is the short circuit current

On the J-V characteristic, close to the open circuit, the solar cell operates like a real voltage generator, which resembles an ideal voltage generator with an internal series resistance $R_{s}$ which causes a voltage drop resulting in a decrease of the output voltage.

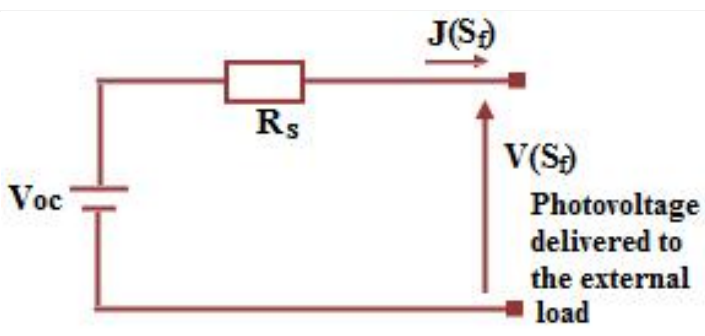

Figure 3: Electrical model of the solar cell near open circuit
The expression of the photovoltage across the external load is:

$$
V\left(S_{f}\right)=V_{c o}-R_{s} . J\left(S_{f}\right)
$$

And then series resistance is :

$$
R_{s}=\frac{V_{c o}-V\left(S_{f}\right)}{J\left(S_{f}\right)}
$$

$V_{c o}$ is the open circuit voltage 


\section{RESULTS AND DISCUSSION}

\subsection{Effect of light concentration on shunt resistance}

Figures 4 and 5 follow show the effect of light intensity on the short circuit current and shunt resistance of the solar cell.

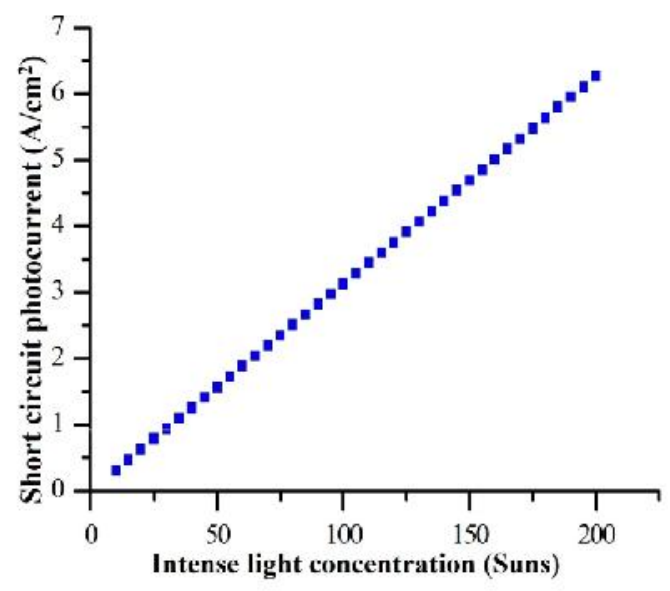

Figure 4: Effect of light intensity on short circuit current density

We observe on these figures that with the increase of light intensity, the short circuit current density increases whereas the shunt resistance decreases. The increase of short circuit current density means that, the quantity of charge carriers which cross the solar cell junction to participate to the current increase with light intensity increases. This situation is the consequence of the increase of the photogeneration of charge carrier with light intensity [Zoungrana et al., 2011]. If the quantity of carriers which cross the junction

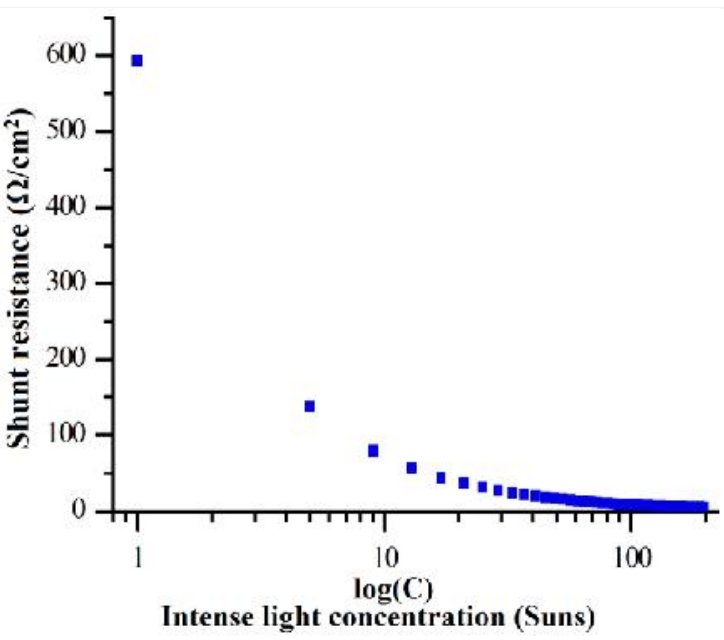

Figure 5: Effect of light intensity on shunt resistance

increase, the number of carriers which disappear in this region also increase. Consequently there will be increase in leakage current and indicating a decrease in shunt resistance.

\subsection{Effect of light concentration on series resistance}

The following figures 6 and 7 show the effect of light intensity on the open circuit photovoltage and the series resistance of the solar cell.

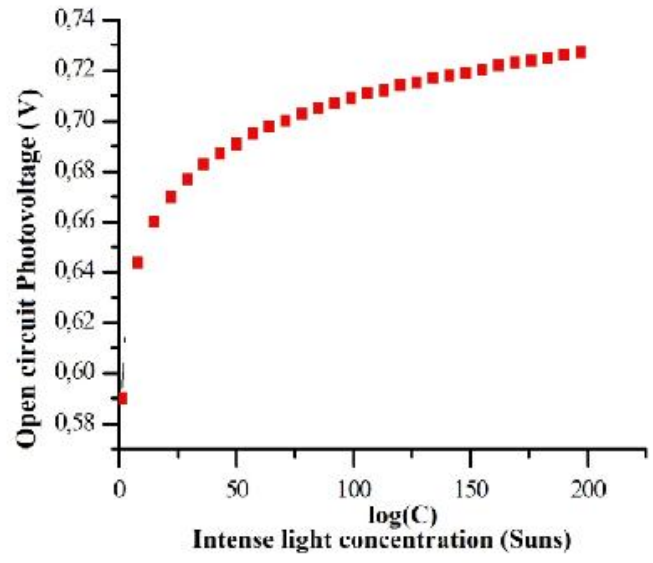

Figure 6: Effect of light intensity on open circuit photovoltage

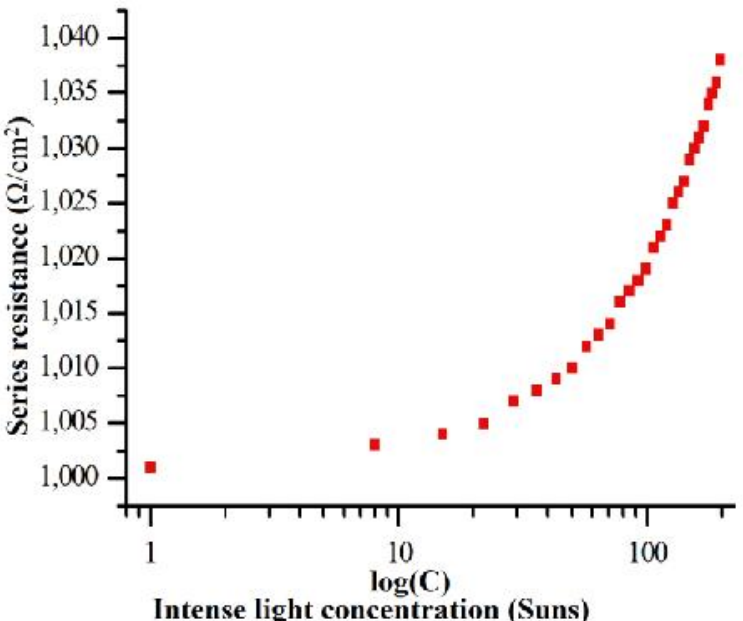

Figure 7: Effect of light intensity on series resistance 
We observe on figures 6 and 7 that with the increase of light intensity, the open circuit voltage and series resistance increase. The increase of open circuit photovoltage with light intensity is the consequence of the increase of the quantity of the charge carriers close to the junction of the solar cell with the increase of light intensity. Indeed, if the quantity of charge carriers increases with the increase of light intensity, in open circuit voltage, all these carriers are blocked near the junction, which reflect as increase in the open circuit voltage. The increase of series resistance with the increase of light intensity is also the consequence of carriers accumulation close the junction. Indeed, the increase of charge carriers presence in solar cell base leads to an increase of their losses and this phenomenon is characterized physically by an increase of the series resistance. The increase of series resistance with the increase of the light intensity will have as consequence an increase of the voltage drop due to the series resistance and then, a decrease of photovoltage across the external charge load.

\subsection{Effect of light concentration on the solar cell electric power}

From equations (7) and (8), the expression of the electric power of the solar cell which is function of junction dynamic velocity $S_{f}$ is expressed as [Zerbo et al., 2011]:

$$
P_{e l}\left(S_{f}\right)=V_{p h}\left(S_{f}\right) \cdot J_{p h}\left(S_{f}\right)
$$

The curves of figure 8 show the effect of the junction dynamic velocity and the light intensity on the electric power delivered to an external load resistance.

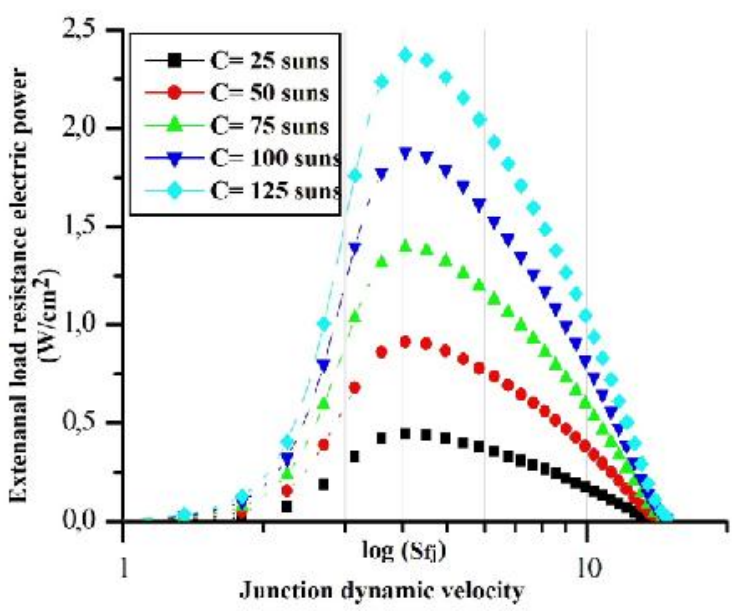

Figure 8: Effect of light intensity on electric power of external load resistance.

We observe on figure 8 that the curves of the electric power of the solar cell have the same shape with those of previous work [Zerbo et al., 2015]. We note also that, in accordance with photovoltage and photocurrent increase with light intensity, the maximum electric power increases with light intensity. We observe also in figure 8 that the maximum of the curves of all values of light intensity have the same value of junction dynamic velocity $S_{f}=10^{3.75}=5623,413 \mathrm{~cm}^{-s^{-1}}$.

Table 1: Light intensity effect on short circuit current, open circuit voltage and maximum electric power.

\begin{tabular}{|l|c|c|c|c|c|}
\hline Light concentration C (suns) & 25 & 50 & 75 & 100 & 125 \\
\hline $\mathrm{Jcc}\left(\mathrm{A} / \mathrm{cm}^{2}\right)$ & 0.783 & 1.565 & 2.348 & 3.13 & 3.913 \\
\hline $\mathrm{Vco}(\mathrm{V})$ & 0.673 & 0.691 & 0.702 & 0.709 & 0.715 \\
\hline $\mathrm{Pel} I_{\max }\left(\mathrm{W} / \mathrm{cm}^{2}\right)$ & 0.452 & 0.931 & 1.421 & 1.917 & 2.419 \\
\hline
\end{tabular}

The results of Table 1 confirm the increase of the short circuit current density, the open circuit voltage and the maximum electric power with increase in light intensity.

\subsection{Effect of light concentration on solar cell conversion efficiency and fill factor}

From the maximum electric power of the solar cell and the illumination light power, its conversion efficiency is expressed as [Zerbo et al., 2015; El-Shaer et al., 2014;

$$
\eta=\frac{P_{\text {elmax }}}{P_{\text {inc }}}
$$

$P_{\text {inc }}$ is the power of the incident light flux. For a solar cell under light illumination intensity and under Air Mass of 1,5 standard conditions $\left(1000 \mathrm{~W} / \mathrm{m}^{2}\right)$, the power of incident light is around $720 \mathrm{~W} / \mathrm{m}^{2}$ [Equer, 1994]. 
Thus, for a $\mathrm{C}$ suns light concentration, $P_{i n c}$ is assume to be: $P_{\text {inc }}=0,072 \mathrm{~W} / \mathrm{cm}^{2} x C=R \mathrm{~W} / \mathrm{cm}^{2}$.

Given the short circuit current and the open circuit voltage, we can also deduce the solar cell fill factor as given in equation (13) [El-Shaer et al., 2014; Barro et al., 2015]:

$$
F F=\frac{P_{e l_{\text {max }}}}{V_{c o} \cdot J_{c c}}
$$

Table 2 below shows the effect of intense light concentration on the solar cell fill factor and conversion efficiency.

Table 2: Light intensity effects on solar cell fill factor and conversion efficiency.

\begin{tabular}{|l|l|l|l|l|l|}
\hline Light concentration C (suns) & 25 & 50 & 75 & 100 & 125 \\
\hline$P_{\text {in }}\left(W / \mathrm{cm}^{2}\right)$ & 1.8 & 3.6 & 5.4 & 7.2 & 9 \\
\hline$P e l_{\max }\left(W / \mathrm{cm}^{2}\right)$ & 0.452 & 0.931 & 1.421 & 1.917 & 2.419 \\
\hline Fill factor FF & 0.8576 & 0.8609 & 0.8621 & 0.8638 & 0.8646 \\
\hline Efficiency $\eta(\%)$ & 25.111 & 25.861 & 26.315 & 26.625 & 26.878 \\
\hline
\end{tabular}

The results in table 2 show that the fill factor and the conversion efficiency of the solar cell increase with increase in light intensity. The increase of the fill factor with light concentration is thoroughly in agreement with the open circuit voltage and short circuit current increase with light intensity. The fill factor is the ratio representing the maximum electric power which can be extracted from a solar cell as oppose to the real electric power produce by the solar cell. This behavior means that, the quantity of charge carriers photogenerated in the base of the solar cell which cross the solar cell's junction increases with light intensity. The increase of carriers photogenaration in solar cell base leads also to an increase of the losses of carrier in this region, which can be physically interpreted by the increase of the solar cell series resistance increase [Zoungrana et al., 2011].

The solar cell conversion efficiency increases with the light intensity. That means that the quantity of carriers that cross the solar cell junction to participate to current increases with light intensity. This behavior also means that the decrease of solar cell's shunt resistance with light intensity does not imply a degradation of the performance of the solar cell. Rather it is an increase of carriers losses at the solar cell's junction due to the increase of charge carriers presence at the junction.

\section{CONCLUSION}

This work put in evidence that, with the increase of intense light intensity, the quantity of carriers photogenerated in the base of the solar cell and which cross the junction increases. The increase of carriers generation in the base further leads to an increase of carriers recombination in this base of the solar cell. The recombination of carriers in the base of the solar cell is characterized by the increase of the series resistance of the solar cell. Also the increase of the quantity of carriers that cross the solar cell's junction leads also to an increase of carriers losses at the solar cell's junction. The increase of carriers losses at the junction of the solar cell is characterized by the decrease of the shunt resistance of the solar cell.

Although carrier losses increase in the base of the solar cell and its junction, we observe that the short circuit current density and the open circuit voltage increase with light intensity increase, and then lead to the increase of solar cell's fill factor. In the same way, we observe that although the recombination at junction increases with light intensity, it appears through this study that the electric power delivered by the solar cell to an external load resistance increases with light intensity. This increase leads to an increase of solar cell's conversion efficiency. The increase of solar cell's fill factor and its conversion efficiency with light intensity increase means that light intensity increase improves the performance of the solar cell.

\section{ACKNOWLEDGMENT:}

The authors wish to thank International Science Program (ISP) for funding our research group and allowing to conduct these works.

\section{REFERENCES}

Barro, F. I., Sané, M and Zouma, B., 2015. Theoretical Investigation of Base Doping and Illumination Level Effects on a Bifacial Silicon Solar Cell. British Journal of Applied Science \& Technology, 7, (6): 610-618.

Deme, M. M., Mbodji, S., Ndoye, S., Thiam, A., Dieng, A and Sissoko, G., 2010. Influence of illumination incidence angle, grain size and grain boundary recombination velocity on the facial solar cell diffusion capacitance. Revue des Energies Renouvelables, 13, (1): $109-121$.

Equer, B., 1993. Energie solaire photovoltaïque, volume 1, Ellipses.

El-Shaer, A., Tadros, M. T. Y and Khalifa, M. A., 2014. Effect of Light intensity and Temperature on Crystalline Silicon Solar Modules Parameters. International Journal of Emerging Technology and Advanced Engineering, 4, (8): 311- 318

Garrido, C. L., Stolik, D., Rodriguez, J and Morales A.,

1999. Influence of carrier recombination in the space charge region on minority carrier life time in the base region of solar cell. Solar Energy Materials \& Solar Cells, 57: 239-247.

Gupta, B., Shishodia, P. K., Kapoor, A., Mehra, R. M., Tetsuo, S., Takashi, J and Masayoshi, U., 2002. Effect of illumination intensity and temperature on the I2V characteristics of $\mathrm{n}-\mathrm{C} / \mathrm{p}-\mathrm{Si}$ heterojunction. 
Solar Energy Materials \& Solar Cells, 73: 261267.

Khan, F., Singh, S. N and Husain M., 2010. Effect of illumination intensity on cell parameters of a silicon solar cell. Solar Energy Materials \& Solar Cells, 94: 1473-1476.

Ohtsuka, H., Sakamoto, M., Koyama, M., Muramatsu, S., Yazawa, Y., Warabisako, T., Abe, T and Saitoh, T., 2001. Effect of light degradation on bifacial Si-Solar cells. Solar Energy Materials \& Solar Cells, 66: 51-59.

Pelanchon, F., Sudre, C and Moreau, Y., 1992. Solar cells under intense light concentration: numerical and analytical approaches. $11^{\text {th }}$ European Photovoltaic Solar Energy conference Montreux 1992: 12-16.

Sané, M and Barro, F. I., 2015. Effect of both magnetic field and doping level on series and shunt resistances. Indian Journal of Pure an Applied Physics, 53: 590-595.

Sissoko, G., Corréa, A., Nanéma, E., Diarra, M. N., Ndiaye, A. L and Adj, M., 1998. Recombination parameters measurement in silicon double sided surface field solar cell. World Renewable Energy Congress: 1856-1859.

Vardanyan, R. R., Kerst, U., Wawer, P and Wagemann, H., 1998. Method for measurement of all recombination parameters in the base region of solar cells. Proceeding of $2^{\text {nd }}$ World Conference and Exhibition on Photovoltaic Solar Energy Conversion. Vienna, Austria, 1: 191-193.
Zerbo, I., Zoungrana, M., Seré, A. D., Ouedraogo, F., Sam, R., Zouma, B and Zougmoré, F., 2011. Influence d'une onde électromagnétique sur une photopile au silicium sous éclairement multispectral en régime statique. Revue des Energies Renouvelables, 14, (3): 517-532.

Zerbo, I., Zoungrana, M., Sourabie, I., Ouedraogo, A., Zouma, B and Bathiebo, D. J., 2015. External magnetic field effect on bifacial silicon solar cell's electric power and conversion efficiency. Turkish Journal of Physics (Turk J Phys), 39: 288-294.

Zouma, B., Maiga, A. S., Dieng, M., Zougmoré, F and Sissoko, G., 2009. 3D approach of spectral response for a bifacial silicon solar cell under a constant magnetic field. Global journal of pure and applied sciences, 15, (1): 117-124.

Zoungrana, M., Zerbo, I., Ouedraogo, F., Zouma, B and Zougmore, F., 2012. 3D modelling of magnetic field and ligth concentration effects on a bifacial silicon solar cell illuminated by its rear side IOP Conf. Ser.: Mater. Sci. Eng._2012, 29, 012020.

Zoungrana, M., Zerbo, I., Seré, A. D., Zouma, B and Zougmoré, F., 2011. 3D Study of Bifacial Silicon Solar Cell Under Intense Light Concentration and Under External Constant Magnetic Field: Effect of magnetic field on carriers mobility and carriers density. Global Journal of Engineering Research, 1\&2, (10): 113-124. 